\title{
Comparison of the Effectiveness of Existential, Cognitive- Existential, and Humanistic-Existential Group Psychotherapy on Psychosomatic Complaints in Women With Type 2 Diabetes Mellitus
}

\author{
Ghaffar Nasiri Hanis \\ Lorestan University \\ Masoud Sadeghi ( $\sim$ Sadeghi.m@lu.ac.ir) \\ Lorestan University \\ Simin Gholamrezaei \\ Lorestan University
}

\section{Research}

Keywords: existential psychotherapy, cognitive-existential, humanistic-existential, psychosomatic complaints, type 2 diabetes mellitus

Posted Date: July 2nd, 2020

DOI: https://doi.org/10.21203/rs.3.rs-37410/v1

License: (c) (i) This work is licensed under a Creative Commons Attribution 4.0 International License. Read Full License 


\section{Abstract}

Background and aims: A significant amount of previous studies has confirmed the positive effect of existential, cognitiveexistential, and humanistic-existential interventions on psychosocial problems with different populations. However, research on the effectiveness and comparison of the effect of these three independent variables on the problem of patients with type 2 diabetes mellitus is novel. So, the purpose of this research is to study the comparison of the effectiveness of existential, cognitive-existential, and humanistic-existential group psychotherapy on psychosomatic complaints among women with type 2 diabetes mellitus.

Methods: The method of the research was semi-experimental, and its experimental design includes the pretest, post-test, and two-month follow-up tests with experimental and control parallel groups. Cases of this study included women with type 2 diabetes mellitus referring to the Specialist Diabetes Clinic of Tohid Hospital in Sanandaj in the first three months of 2019. 32 subjects selected by simple random sampling method of this society and were assigned to three experimental and one control group by substituting random method. The data collected based on the scale of psychosomatic complaints Takata \& Sakata (2004). After the pre-test, the experimental groups participated in 120-minute sessions for 9 weeks. Data analyzed by the statistical test of repeated measures of the General Linear Model.

Results: The results of repeated measures analysis showed that the effect of the interventions in experimental groups of psychosomatic complaints was significant and stable compared to the control group (computed using alpha $=0,05$ ). The effect of the group humanistic-existential psychotherapy on reducing psychosomatic complaints about women with type 2 diabetes mellitus is stable and significant compared to existential and cognitive-existential psychotherapy (The mean difference is significant at the 0,05 level).

Conclusion: The findings show applying cognitive-existential more benefits than the other two method. So, existentialcognitive group therapy could be a selective therapy for reducing psychosomatic complaints about women with type 2 diabetes mellitus.

\section{Background}

Psychosomatic symptoms are psychological problems that emerged from the bodies but are rooted in acute stress and psychological dynamics. Type 2 diabetes mellitus is one of the most prevalent of these problems (1). Type 2 diabetes mellitus considered a psychosomatic illness and is the third leading cause of death in the world and is one of the most common illnesses that emerge as the form of physical symptoms $(2,3)$. This illness is significantly correlated with psychological stress and mental disorders. It as well as mental disorders are common and may occur with one another and/or one may worsen the other (4) Insofar as exact screening for psychological problem comorbidities is necessary for type 2 diabetes mellitus patients (5). Studies at the end of the twentieth century showed that the mortality rated for women with type 2 diabetes mellitus were still higher than the normal population. To the extent that the all-cause mortality rates difference between women with type 2 diabetes mellitus and non-diabetic women more than doubled (6). Psychological interventions can have beneficial effects on diabetic patient's mental health (7). So, the comparison of the effectiveness of existential, cognitive-existential, and humanistic-existential group psychotherapy on psychosomatic complaints in women with type 2 diabetes mellitus is important for their improving physical, mental, and social life.

\section{Existential group psychotherapy}

Unlike other methods of counseling and psychotherapy that have a psychological root, existential methods have derived directly from philosophy. Existential psychotherapy derives from the existential philosophical thoughts that founded by Søren Kierkegaard (1813-1855) and propagate by Jean-Paul Sartre (1905-1980) $(8,9)$. Existential issues in group psychotherapy derive from existential thought both as a philosophy and as a value system. Its origins derive from the weakening of traditional values and the growing alienation of humans from himself (10). Existential psychotherapy is a 
dynamic method of therapy that focuses on the concerns caused by human existence. The principles of existential psychotherapy include addressing specific themes such as self-awareness, free will, existential anxiety, responsibility, loneliness, death anxiety, existential vacuum, meaning search, meaning in life and death $(11,12)$. Existential psychotherapy involves a kind of philosophical perspective instead of a set of techniques (13). The unique themes of existentialism such as aloneness, responsibility, and freedom are universal to humankind. In including existential concerns as part of group psychotherapy, therapist and patients move more closely to bilateral relationships and subjective interactions (10). One of the main tasks of an existential therapist is to make the patient aware that he or she is not going to act like a passive being whose events determine his or her life and his or her goals. Instead, he or she can consciously shape his or her plan $(13,14)$.

\section{Cognitive existential group psychotherapy}

Cognitive-existential group psychotherapy is an integrated method created by a logical combination of theoretical and strategic principles of existential psychotherapy and cognitive techniques and strategies of cognitive psychotherapy (15). Integrated psychotherapy methods derived from the combination principles, concepts, and methods of two or more main theories and methods are more effective than the one-dimensional methods that use their structures, concepts, and assumptions to explanation a wide range of human phenomena. Different populations provide psychological support to help alleviate the problem (16). It seems significant that, within the move towards therapeutic integration, little has been a study on a potential relationship between existential-phenomenological and cognitive-behavior therapies and the effect of them. Given that both these approaches emphasize the concept of meaning in working towards psychological growth and change, this omission seems important to researching (17). In Cognitive-existential group psychotherapy, the patients have the opportunity to express his or her existential concerns and current anxieties when applying cognitive strategies, such as identifying, changing, and correcting the various cognitive distortion that leads to undesirable behaviors. This is a combination of cognitive reassessment and coping skills that integrated with existential and group supportive strategic factors. Patients, however, also benefit from the support of participating in group intervention used in the context of group therapy(15).

\section{Humanistic-existential group psychotherapy}

Humanistic-existential psychotherapy that developed when the humanistic psychology movement emerged in the 1950 s is also derived from existential philosophy (18). It emphasizes existential certainties concerns and subjective experience(18).The humanistic-existential group psychotherapy method is a combination of concepts and applications based on existential values such as self-inquiry, struggle, and responsibility, and popular values such as spontaneity, optimism, and practicality. It is a kind of psychotherapy that, by emphasizing the current reality and by analyzing and replacing specific patterns of response, is an encouragement to help people actuality their potential. This process facilitated in a group environment, because in the humanistic-existential group psychotherapy through interaction with others, more aspects of patients existential certainties concerns are revealed (19) humanistic-existential group psychotherapy involves situations in which people can sincerely recognize themselves and realize their ideas as much as possible (20) .

\section{Logic of research}

Helping women with type 2 diabetes mellitus through psychological intervention is very important. Because, it is clear psycho-somatic problems, which women more experience it symptoms than men (21), associated with a higher prevalence of psychological problems (22). The main features of psychological factors influencing on diabetes, presence of one or more clinically significant psychological or behavioral factors that are a harmful way with an increased risk of suffering death or disability affects the medical condition(23). Simple existential interventions and integrated with other interventions, in addition to addressing existential concerns that can increase acceptance of reality and thus reduce stress, also address various aspects of existence such as the physical, mental, and social worlds that can effective in reducing the negative psychological effects on the body. In these interventions, patients learn to set up a good relationship with themselves, their bodies, and others (13). 


\section{Research background}

In review the evidence of the effectiveness types of existential therapies, the result shows that some of them appear beneficial to some populations. There is significant support for interventions incorporating psycho-education, exercises, and discussing meaning in life directly and positively with physically ill patients (24).

Investigation of the effectiveness of group psychotherapy for problem reduction in patients with type 2 diabetes mellitus shows that limited experience of group psychotherapy among these patients has given encouraging results. The issue remains, however, as to which groups of patients might benefit most(25). Research by Nazari, Yarahmadi, and Zahrakar (26) showed that group psychotherapy increased the marital satisfaction of women with type 2 diabetes mellitus. The findings of the investigation of the effectiveness of existential group psychotherapy have shown that this intervention has been more effective in reducing the problem of the mastectomy in women compared to group reality therapy(27). Existential-cognitive group therapy could be a selective therapy to improve the psychological stress of depressed women suffering from breast cancer (15), (28) Also, humanistic-existential group therapy could be a selective therapy for borderline personality disorder treatment (29).

Given the very significant limitations of the research on the comparison of the effectiveness of existential, cognitiveexistential, and humanistic-existential group psychotherapy on psychosomatic complaints in women with type 2 diabetes mellitus, comparing the effect of these interventions can enrich of psychotherapy try for women with type 2 diabetes mellitus and benefits from reducing this gap. Therefore, this study was conducted to answer the following questions.

1. be effective any existential, cognitive-existential, and humanist-existential group psychotherapies compared to the

2. Which group of existential, cognitive-existential, and humanist-existential psychotherapy has the greatest impact on women's psychosomatic complaints with women with type 2 diabetes mellitus?

\section{Materials And Methods}

\section{Study design}

This research is a randomized clinical trial conducted by the semi-experimental method and using a pre-test, post-test design and a two-month follow-up test with three parallel experimental groups and one control group. The clinical trial study protocol of this research has registered in the Iranian Registry of Clinical Trials with the code number IRCT20150104020553N1.

\section{Study variables}

The independent variables of research are existential group psychotherapy, cognitive-existential group psychotherapy, and humanistic-existential group psychotherapy, and the dependent variable of research is psychosomatic complaints.

\section{Study population and subjects}

The target population of this study was women with type 2 diabetes mellitus that referred to the Diabetes Clinic of Tohid Hospital in Sanandaj in the first three months of $1398 \mathrm{AH}$. After sampling, there were 32 subjects assigned to three experimental groups and one control group. The entry criteria, including type 2 diabetes, according to the diagnosis of the Specialists of this Diabetes Clinic, conscious consent to take part in the sessions; Patients were not treated by a psychologist or psychiatrist. Elimination criteria also include taking the absence of more than two sessions, incomplete answers to scale, or half-finished tool answers, Failure to respond to the scale was a pre-test, post-test, and a test of tracking and dumping data onto statistical analysis .

\section{Sampling}


Subjects were randomly selected from 1900 women with type 2 diabetes mellitus who referred to the Diabetes Clinic of Tohid Hospital in Sanandaj and assigned to three experimental groups and one control group using the random substitution method.

\section{Measurements}

Psychosomatic complaints levels determined using the 30 -item of the Persian version of the scale of the psychosomatic complaints developed by Takata \& Sakata(30). Standardization and assurance of the validity and reliability of the Persian version of this scale was first performed by Hajloo (22) Scoring in this scale is a 4-point Likert scale for the "Never", "Rare", "Sometimes" and "Frequently" options, with scores of 0, 1, 2, and 3, respectively. A score between 0 and 30 indicates low levels of psychotic complaints. A score between 30 and 45 indicates a moderate level of psychiatric complaints, and a score above 45 indicates a high rate of psychotic complaints. The creators of this scale, by calculating its correlation with Goldberg's mental health scale, obtained the simultaneous validity of it in two separate studies, 0.64 and 0.65 . The scale reliability obtained by Cronbach's alpha method as 0.93 in 1997, 0.91 in 1998 and 0.92 in 1999(22). In the present study, instrument reliability was calculated with Cronbach's alpha and obtained for (0.78).

\section{Interventions}

Existential, cognitive-existential, and humanistic-existential groups participated separately in nine 120-minute weekly sessions. Existential group psychotherapy program accordance with the method developed by Corey (13), Cognitiveexistential group psychotherapy program accordance with the method developed by Ottens \& Hanna (31) And the humanistic-existential group psychotherapy program in accordance with the method developed by Schneider \& Krug (19). 
Table 1: Summarizes the content of sessions of existential group psychotherapy, cognitive-existential group psychotherapy, and humanistic-existential group psychotherapy.

\begin{tabular}{|c|c|c|}
\hline sessions & existential group & cognitiveexistential group \\
\hline 1 & $\begin{array}{l}\text { Explain the structure, the process of } \\
\text { evaluation and treatment and goals } \\
\text { of the sessions, group rules with a } \\
\text { focus on ethical and } \\
\text { communication principles; } \\
\text { introducing about themes sessions }\end{array}$ & $\begin{array}{l}\text { Explain the structure, content, rules, } \\
\text { method of session holding; value } \\
\text { and goals by focus on ethical and } \\
\text { communication principles; Assess } \\
\text { members' knowledge and views on } \\
\text { psychosomatic complaints }\end{array}$ \\
\hline
\end{tabular}

2 Existential self-awareness and free will; facilitate the presence here and now; expanding the self-awareness in response to the question "Who am I?"
Logical foundations of the cognitive- existential method and its pathological and therapeutic perspective; body and psycho; different types of cognitions

Cognitive and existential psych determinism, anxiety resulting from the choices and actions based on cognitions; free will and responsibility through the cognitive assessment

Anxiety caused by Free will and addressing to responsibility; anxiety and guilt over the current choices; benefits of existential anxiety

\section{humanistic-existential group}

Structure, process of evaluation and treatment; goals of the sessions, explain the group rules with a focus on ethical and communication principles; Establish a therapeutic alliance

Self-awareness and selfconcept by Focusing on personal abilities; Facilitate increased attendance here and now by focusing on communication style

Effective change responsibility; Exploring the personal impact on the current state of life to acceptance its role in creating an interpersonal status; anxiety from members' current choices

4 Choice, decision and action on quality of life; intentionality and how destiny determined based on the selection and perception of destiny as a ground for re-selection, purpose, and goals

$5 \quad$ intimacy and isolation and awareness of existential loneliness; Exchange of views on intimacy, love, and interpersonal conflict by focusing on modeling l-you dialogue; the difference between authentically and imitation in relation to others Increase death awareness through dialogue about the death reality as an existential certainty; the importance of awareness of mortality for the high quality of life
Cognitive distortions and it express; the role of choice, decision, and action in life quality; intentionality and selection in Cognitive and existential view

Dialectical Socratic by examples for thesis, antithesis, and synthesis to correct ineffective beliefs about psychophysical mechanisms; members' views on intimate relationships and isolation with a focus on originality and existential loneliness

Planning in the framework of setting short-term, medium-term and longterm goals based on personal needs and goals; Increasing death awareness through discourse about death reality as a certain event
Real self and the ideal self; Expressing current values of members; facilitator autonomy and new values; expectations in interpersonal situations

Self-disclosure and express somatic and psychological problems; Acceptance the self and others; unconditional positive regard; exchange of views on intimacy, love, and interpersonal conflict

Here and now; expression of gratitude; awareness on body and mortality to life enhancement; potentials and actualization, and discuss on characteristics of people with selfactualization

Dialectics about existential vacuum and the meaning of life; Explain the role of values, meaning of life by focusing on the values development, goals and lifestyle
Facilitate the use of active listening, verbal and behavioral feedback in here and now; Facilitate the use of empathy by role-playing meaning of life; searching meaning in suffering and coping with the existential vacuum of life by focusing on the current state of health

Talk about perceived change; Discussion on; group experience in sessions and its consequences from the members' point of view.
Discussion on feedbacks; Examining members' views on how much this session has affected their psychosomatic status; reviewing the theme of sessions
Perceived change; Discussion on feedback; Explain the experience of group changes and its consequences by the members' report 
Expressions about perceived learning and existential changes
Summarizing sessions by reviewing the of expressing the perceived experiences and changes
Intimacy conversation about group experiences with a focus on group dynamics and providing empathy and feedback

\section{Statistical analysis}

Statistical analyses were performed using SPSS. Descriptive statistical and inferential statistical tests, including the statistical test of repeated measures of the general linear model and Benfroni follow-up tests used to analyze the data. Differences considered significant at the $\mathrm{P}<.050$ level. The test results from Levene's Test of Equality of Error Variances that tests the null hypothesis that the error variance of the dependent variable is equal to groups and Mauchly's Test of Sphericity that tests the null hypothesis that the error covariance matrix of the orthonormalized transformed dependent variables is proportional to an identity matrix, showed that the use of the statistical test of repeated measures of the general linear model is Unobstructed.

\section{Results:}

\section{Subject characteristics}

The mean and standard deviation from the age of the control group members was 38.3 and 4.8: members of the existential group 37 and 2/6; the members of the cognitive-existential group were 39.9 and 4.7 and the members of the humanisticexistential group were 42.2 and 7.3. The mean and standard deviation from all subjects was 39.4 and 5.8. Mean and standard deviation of marriage duration of members of control group 15.3 and 3.2; members of the existential group 10/8 and 4/9; members of the cognitive-existential group were 9.6 and 1.4 and the members of the humanistic-existential group were 8.6 and 4.4. The mean and standard deviation duration of marriage to all subjects was 11 and 1.4. In employment, $89 \%$ of subjects were housewives, and $11 \%$ employed. 
Table 2: Descriptive Statistics; Mean and standard deviation of psychosomatic complaints

\begin{tabular}{|lllll|}
\hline & Groups & Mean & Std. Deviation & N \\
\hline Pre-test. Psychosomatic complaints & Existential & 41.0000 & 5.00000 & 8 \\
\cline { 2 - 5 } & Cognitive-existential & 35.0000 & 5.00000 & 8 \\
\cline { 2 - 5 } & Humanistic-existential & 45.0000 & 6.00000 & 8 \\
\hline & Control & 38.0000 & 3.00000 & 8 \\
\cline { 2 - 5 } Post-test. Psychosomatic complaints & Total & 40.0938 & 6.00000 & 32 \\
& Existential & 35.0000 & 4.00000 & 8 \\
\cline { 2 - 5 } & Cognitive-existential & 30.0000 & 3.06769 & 8 \\
\cline { 2 - 5 } & Humanistic-existential & 30.0000 & 7.00000 & 8 \\
\cline { 2 - 5 } & Control & 38.0000 & 5.00000 & 8 \\
\cline { 2 - 5 } & Total & 33.0000 & 6.00000 & 32 \\
\hline Follow-up test. Psychosomatic complaints & Existential & 34.0000 & 3.00000 & 8 \\
\cline { 2 - 5 } & Cognitive-existential & 27.0000 & 5.00000 & 8 \\
\cline { 2 - 5 } & Humanistic-existential & 29.0000 & 7.00000 & 8 \\
\hline & Control & 37.0000 & 3.00000 & 8 \\
\hline & Total & 32.0937 & 6.00000 & 32 \\
\cline { 2 - 5 } & & & & \\
\hline
\end{tabular}

The results of Multivariate Tests in Table 3 showed that the statistics of the Pillai's Trace, Wilks' Lambda, Hotelling's Trace and Roy's Largest Root were significant; therefore Interventions are effective on the linear composition of the dependent variable and there are significant differences between the groups. 
Table 3: Multivariate Testsa; Multivariate Tests results in three measurements and groups

\begin{tabular}{|c|c|c|c|c|c|c|c|c|c|}
\hline Effect & & Value & $F$ & $\begin{array}{l}\text { Hypothesis } \\
\text { df }\end{array}$ & $\begin{array}{l}\text { Error } \\
\text { df }\end{array}$ & Sig. & $\begin{array}{l}\text { Partial } \\
\text { Eta } \\
\text { Squared }\end{array}$ & $\begin{array}{l}\text { Noncent. } \\
\text { Parameter }\end{array}$ & $\begin{array}{l}\text { Observed } \\
\text { Powerd }\end{array}$ \\
\hline \multirow[t]{4}{*}{ Tests } & Pillai's Trace & .000 & $34.000^{\mathrm{b}}$ & 2.000 & 27.000 & .000 & .000 & 68.000 & .000 \\
\hline & $\begin{array}{l}\text { Wilks' } \\
\text { Lambda }\end{array}$ & .000 & $34.000^{b}$ & 2.000 & 27.000 & .000 & .000 & 68.000 & .000 \\
\hline & $\begin{array}{l}\text { Hotelling's } \\
\text { Trace }\end{array}$ & 2.000 & $34.000^{\mathrm{b}}$ & 2.000 & 27.000 & .000 & .000 & 68.000 & .000 \\
\hline & $\begin{array}{l}\text { Roy's } \\
\text { Largest Root }\end{array}$ & 2.000 & $34.000^{b}$ & 2.000 & 27.000 & .000 & .000 & 68.000 & .000 \\
\hline \multirow{4}{*}{$\begin{array}{l}\text { Tests * } \\
\text { Groups }\end{array}$} & Pillai's Trace & .000 & 3.000 & 6.000 & 56.000 & .004 & .000 & 21.000 & .000 \\
\hline & $\begin{array}{l}\text { Wilks' } \\
\text { Lambda }\end{array}$ & .000 & $4.000^{b}$ & 6.000 & 54.000 & .002 & .000 & 24.000 & .000 \\
\hline & $\begin{array}{l}\text { Hotelling's } \\
\text { Trace }\end{array}$ & 1.078 & 4.000 & 6.000 & 52.000 & .001 & .000 & 28.034 & .000 \\
\hline & $\begin{array}{l}\text { Roy's } \\
\text { Largest Root }\end{array}$ & 1.026 & $9.000^{\mathrm{c}}$ & 3.000 & 28.000 & .000 & .000 & 28.000 & .000 \\
\hline
\end{tabular}

a. Design: Intercept + Groups

Within Subjects Design: Tests

b. Exact statistic

c. The statistic is an upper bound on $\mathrm{F}$ that yields a lower bound on the significance level.

d. Computed using alpha $=, 05$

Table 4 shows the results of the Tests of Within-Subjects Effects and in Table 5 the Tests of Within-Subjects Contrasts for all four groups in the three stages of pretest, post-test, and follow-up test. Table 4 shows that the Within-Subjects Effects on the time factor and the interaction of time and groups according to the Lower-bound statistic are significant (computed using alpha $=, 05$ ). Table 5 shows that the experimental contradictions of the subjects in the factor of linear and Quadratic stages time are significant (computed using alpha $=, 05$ ). 
Table 4: Tests of Within-Subjects Effects

\begin{tabular}{|c|c|c|c|c|c|c|c|c|c|}
\hline Source & & $\begin{array}{l}\text { Type III } \\
\text { Sum of } \\
\text { Squares }\end{array}$ & df & $\begin{array}{l}\text { Mean } \\
\text { Square }\end{array}$ & $F$ & Sig. & $\begin{array}{l}\text { Partial } \\
\text { Eta } \\
\text { Squared }\end{array}$ & $\begin{array}{l}\text { Noncent. } \\
\text { Parameter }\end{array}$ & $\begin{array}{l}\text { Observed } \\
\text { Power }^{\text {a }}\end{array}$ \\
\hline \multirow[t]{4}{*}{ Tests } & $\begin{array}{l}\text { Sphericity } \\
\text { Assumed }\end{array}$ & 1157.000 & 2 & 578.000 & 38.000 & .000 & .000 & 77.000 & .000 \\
\hline & $\begin{array}{l}\text { Greenhouse- } \\
\text { Geisser }\end{array}$ & 1157.000 & 1.000 & 668.000 & 38.000 & .000 & .000 & 67.000 & .000 \\
\hline & Huynh-Feldt & 1157.000 & 2.000 & 578.000 & 38.000 & .000 & .000 & 77.000 & .000 \\
\hline & $\begin{array}{l}\text { Lower- } \\
\text { bound }\end{array}$ & 1157.000 & 1.000 & 1157.000 & 38.000 & .000 & .000 & 38.000 & .000 \\
\hline \multirow[t]{4}{*}{$\begin{array}{l}\text { Tests * } \\
\text { Groups }\end{array}$} & $\begin{array}{l}\text { Sphericity } \\
\text { Assumed }\end{array}$ & 566.000 & 6 & 94.000 & 6.000 & .000 & .000 & 38.000 & .000 \\
\hline & $\begin{array}{l}\text { Greenhouse- } \\
\text { Geisser }\end{array}$ & 566.000 & 5.000 & 109.097 & 6.000 & .000 & .000 & 33.032 & .000 \\
\hline & Huynh-Feldt & 566.000 & 6.000 & 94.000 & 6.000 & .000 & .000 & 38.000 & .000 \\
\hline & $\begin{array}{l}\text { Lower- } \\
\text { bound }\end{array}$ & 566.000 & 3.000 & 188.000 & 6.000 & .002 & .000 & 19.087 & .000 \\
\hline \multirow[t]{4}{*}{ Error(Tests) } & $\begin{array}{l}\text { Sphericity } \\
\text { Assumed }\end{array}$ & 830.000 & 56 & 14.000 & & & & & \\
\hline & $\begin{array}{l}\text { Greenhouse- } \\
\text { Geisser }\end{array}$ & 830.000 & 48.000 & 17.000 & & & & & \\
\hline & Huynh-Feldt & 830.000 & 56.000 & 14.000 & & & & & \\
\hline & $\begin{array}{l}\text { Lower- } \\
\text { bound }\end{array}$ & 830.000 & 28.000 & 29.000 & & & & & \\
\hline
\end{tabular}

Table 5: Tests of Within-Subjects Contrasts

\begin{tabular}{|c|c|c|c|c|c|c|c|c|c|}
\hline Source & Tests & $\begin{array}{l}\text { Type III Sum of } \\
\text { Squares }\end{array}$ & $\mathrm{df}$ & $\begin{array}{l}\text { Mean } \\
\text { Square }\end{array}$ & $\mathrm{F}$ & Sig. & $\begin{array}{l}\text { Partial } \\
\text { Eta } \\
\text { Squared }\end{array}$ & $\begin{array}{l}\text { Noncent. } \\
\text { Parameter }\end{array}$ & $\begin{array}{l}\text { Observed } \\
\text { Power }^{\mathrm{a}}\end{array}$ \\
\hline \multirow[t]{2}{*}{ Tests } & Linear & 1023.000 & 1 & 1023.000 & 70.000 & .000 & .000 & 70.000 & .000 \\
\hline & Quadratic & 133.000 & 1 & 133.000 & 8.000 & .006 & .000 & 8.000 & .000 \\
\hline \multirow{2}{*}{$\begin{array}{l}\text { Tests * } \\
\text { Groups }\end{array}$} & Linear & 391.000 & 3 & 130.000 & 9.039 & .000 & .000 & 27.000 & .000 \\
\hline & Quadratic & 174.000 & 3 & 58.000 & 3.000 & .021 & .000 & 11.000 & .000 \\
\hline \multirow[t]{2}{*}{ Error(Tests) } & Linear & 404.000 & 28 & 14.000 & & & & & \\
\hline & Quadratic & 426.000 & 28 & 15.000 & & & & & \\
\hline
\end{tabular}


Table 6 shows the Tests of Between-Subjects Effects of the mean scores for the groups in the three stages. The results in Table 6 show that the changes in the dependent variable in the study of the Between-Subjects Effects of the means measured three times and the groups were significant (0.01).

Table 6: Tests of Between-Subjects Effects: Transformed Variable: Average

\begin{tabular}{|llcllllll|}
\hline Source & $\begin{array}{l}\text { Type III Sum of } \\
\text { Squares }\end{array}$ & df & $\begin{array}{l}\text { Mean } \\
\text { Square }\end{array}$ & F & Sig. & $\begin{array}{l}\text { Partial Eta } \\
\text { Squared }\end{array}$ & $\begin{array}{l}\text { Noncent. } \\
\text { Parameter }\end{array}$ & $\begin{array}{l}\text { Observed } \\
\text { Power }^{\mathbf{a}}\end{array}$ \\
\hline Intercept & 119356.000 & 1 & 119356.000 & 2187.000 & .000 & .000 & 2187.000 & 1.000 \\
\hline Groups & 728.000 & 3 & 242.000 & 4.000 & .011 & .000 & 13.000 & .000 \\
\hline Error & 1527.000 & 28 & 54.000 & & & & & \\
\hline a. Computed using alpha $=, 05$ & & & & & & & \\
\hline
\end{tabular}

Table 7 presents the pairwise comparisons based on estimated marginal means of the groups. The mean difference is significant at the 0, 05 level. (Data in Tables 6 and 7 adjustment for multiple comparisons: Bonferroni) 
Table 7: Pairwise Comparisons; Based on estimated marginal means

\begin{tabular}{|c|c|c|c|c|c|c|}
\hline \multirow[t]{2}{*}{ (I) Groups } & \multirow[t]{2}{*}{ (J) Groups } & \multirow[t]{2}{*}{$\begin{array}{l}\text { Mean Difference } \\
(1-J)\end{array}$} & \multirow[t]{2}{*}{$\begin{array}{l}\text { Std. } \\
\text { Error }\end{array}$} & \multirow[t]{2}{*}{ Sig. ${ }^{b}$} & \multicolumn{2}{|c|}{$\begin{array}{l}\text { 95\% Confidence Interval for } \\
\text { Difference }^{\text {b }}\end{array}$} \\
\hline & & & & & Lower Bound & Upper Bound \\
\hline \multirow[t]{3}{*}{ Existential } & $\begin{array}{l}\text { Cognitive- } \\
\text { existential }\end{array}$ & $6.000^{*}$ & 2.000 & .046 & .072 & 12.000 \\
\hline & $\begin{array}{l}\text { Humanistic- } \\
\text { existential }\end{array}$ & 2.083 & 2.000 & 1.000 & -3.000 & 8.000 \\
\hline & Cntrol & -1.083 & 2.000 & 1.000 & -7.000 & 4.000 \\
\hline \multirow{3}{*}{$\begin{array}{l}\text { Cognitive- } \\
\text { existential }\end{array}$} & Existential & $-6.000^{*}$ & 2.000 & .046 & -12.000 & -.072 \\
\hline & $\begin{array}{l}\text { Humanistic- } \\
\text { existential }\end{array}$ & -4.042 & 2.000 & .000 & -10.095 & 2.012 \\
\hline & Cntrol & $-7.000^{\star}$ & 2.000 & .013 & -13.000 & -1.000 \\
\hline \multirow{3}{*}{$\begin{array}{l}\text { Humanistic- } \\
\text { existential }\end{array}$} & Existential & -2.083 & 2.000 & 1.000 & -8.000 & 3.000 \\
\hline & $\begin{array}{l}\text { Cognitive- } \\
\text { existential }\end{array}$ & 4.042 & 2.000 & .000 & -2.012 & 10.095 \\
\hline & Cntrol & -3.000 & 2.000 & .000 & -9.000 & 2.000 \\
\hline \multirow[t]{3}{*}{ Cntrol } & Existential & 1.083 & 2.000 & 1.000 & -4.000 & 7.000 \\
\hline & $\begin{array}{l}\text { Cognitive- } \\
\text { existential }\end{array}$ & $7.000^{*}$ & 2.000 & .013 & 1.000 & 13.000 \\
\hline & $\begin{array}{l}\text { Humanistic- } \\
\text { existential }\end{array}$ & 3.000 & 2.000 & .000 & -2.000 & 9.000 \\
\hline \multicolumn{7}{|c|}{ *. The mean difference is significant at the 0,05 level. } \\
\hline \multicolumn{7}{|c|}{ a. Adjustment for multiple comparisons: Bonferroni. } \\
\hline
\end{tabular}

Table 8 presents the pairwise comparisons based on estimated marginal means of the three stages of pretest, post-test, and follow-up tests. The results shown in Table 8 show that the change in psychosomatic complaints in the post-test and followup test is significant compared to the pretest (The mean difference is significant at the 0,05 level). 
Table 8: Pairwise Comparisons; Based on estimated marginal means

\begin{tabular}{|c|c|c|c|c|c|c|}
\hline \multirow[t]{2}{*}{ (I) Tests } & \multirow[t]{2}{*}{ (J) Tests } & \multirow[t]{2}{*}{ Mean Difference (I-J) } & \multirow[t]{2}{*}{ Std. Error } & \multirow[t]{2}{*}{ Sig. ${ }^{b}$} & \multicolumn{2}{|c|}{$95 \%$ Confidence Interval for Difference } \\
\hline & & & & & Lower Bound & Upper Bound \\
\hline \multirow[t]{2}{*}{ pretest } & post-test & $6.000^{*}$ & 1.000 & .000 & 3.000 & 9.000 \\
\hline & follow-up test & $8.000^{\star}$ & .000 & .000 & 5.000 & 10.000 \\
\hline \multirow[t]{2}{*}{ post-test } & pretest & $-6.000^{\star}$ & 1.000 & .000 & -9.000 & -3.000 \\
\hline & follow-up test & 1.000 & .000 & .000 & .000 & 3.000 \\
\hline \multirow[t]{2}{*}{ follow-up test } & pretest & $-8.000^{*}$ & .000 & .000 & -10.000 & -5.000 \\
\hline & post-test & -1.000 & .000 & .000 & -3.000 & .000 \\
\hline
\end{tabular}

The optimal results of Multivariate Tests based on the linearly independent pairwise comparisons among the estimated marginal means, and Univariate Tests that based on the linearly independent pairwise comparisons among the estimated marginal means, shown in Tables 9 and 10.

Table 9 Multivariate Tests; Each F tests the multivariate effect of Tests

\begin{tabular}{|c|c|c|c|c|c|c|c|c|}
\hline & Value & $\mathbf{F}$ & $\begin{array}{l}\text { Hypothesis } \\
\text { df }\end{array}$ & $\begin{array}{l}\text { Error } \\
\text { df }\end{array}$ & Sig. & $\begin{array}{l}\text { Partial Eta } \\
\text { Squared }\end{array}$ & $\begin{array}{l}\text { Noncent. } \\
\text { Parameter }\end{array}$ & $\begin{array}{l}\text { Observed } \\
\text { Power }^{b}\end{array}$ \\
\hline Pillai's trace & .000 & $34.000^{a}$ & 2.000 & 27.000 & .000 & .000 & 68.000 & .000 \\
\hline Wilks' lambda & .000 & $34.000^{a}$ & 2.000 & 27.000 & .000 & .000 & 68.000 & .000 \\
\hline $\begin{array}{l}\text { Hotelling's } \\
\text { trace }\end{array}$ & 2.000 & $34.000^{a}$ & 2.000 & 27.000 & .000 & .000 & 68.000 & .000 \\
\hline $\begin{array}{l}\text { Roy's largest } \\
\text { root }\end{array}$ & 2.000 & $34.000^{a}$ & 2.000 & 27.000 & .000 & .000 & 68.000 & .000 \\
\hline \multicolumn{9}{|c|}{ a. Exact statistic } \\
\hline \multicolumn{9}{|c|}{ b. Computed using alpha $=, 05$} \\
\hline
\end{tabular}


Table 10 Univariate Tests; The F tests the effect of Groups

\begin{tabular}{|c|c|c|c|c|c|c|c|c|}
\hline & $\begin{array}{l}\text { Sum of } \\
\text { Squares }\end{array}$ & df & $\begin{array}{l}\text { Mean } \\
\text { Square }\end{array}$ & $F$ & Sig. & $\begin{array}{l}\text { Partial Eta } \\
\text { Squared }\end{array}$ & $\begin{array}{l}\text { Noncent. } \\
\text { Parameter }\end{array}$ & $\begin{array}{l}\text { Observed } \\
\text { Power }^{a}\end{array}$ \\
\hline Contrast & 242.000 & 3 & 80.000 & 4.000 & .011 & .000 & 13.000 & .000 \\
\hline Error & 509.000 & 28 & 18.000 & & & & & \\
\hline
\end{tabular}

Table 11 shows the Bonferroni Post Hoc Tests for Multiple Comparisons of groups. The results in Table 11 show effect of the group humanistic-existential psychotherapy on reducing psychosomatic complaints about women with type 2 diabetes mellitus is stable and significant compared to existential and cognitive-existential psychotherapy.

Table 11: Multiple Comparisons; Bonferroni Post Hoc Tests Based on observed means

\begin{tabular}{|c|c|c|c|c|c|c|}
\hline \multirow[t]{2}{*}{ (I) Groups } & \multirow[t]{2}{*}{ (J) Groups } & \multirow{2}{*}{$\begin{array}{l}\text { Mean Difference (I- } \\
\text { J) }\end{array}$} & \multirow{2}{*}{$\begin{array}{l}\text { Std. } \\
\text { Error }\end{array}$} & \multirow[t]{2}{*}{ Sig. } & \multicolumn{2}{|c|}{$95 \%$ Confidence Interval } \\
\hline & & & & & $\begin{array}{l}\text { Lower } \\
\text { Bound }\end{array}$ & $\begin{array}{l}\text { Upper } \\
\text { Bound }\end{array}$ \\
\hline \multirow[t]{3}{*}{ Existential } & Cognitiveexistential & $6.0000^{*}$ & 2.00000 & .046 & .0715 & 12.0000 \\
\hline & $\begin{array}{l}\text { Humanistic- } \\
\text { existential }\end{array}$ & 2.0833 & 2.00000 & 1.000 & -3.0000 & 8.0000 \\
\hline & Cntrol & -1.0833 & 2.00000 & 1.000 & -7.0000 & 4.0000 \\
\hline \multirow[t]{3}{*}{ Cognitive-existential } & Existential & $-6.0000^{*}$ & 2.00000 & .046 & -12.0000 & -.0715 \\
\hline & $\begin{array}{l}\text { Humanistic- } \\
\text { existential }\end{array}$ & -4.0417 & 2.00000 & .000 & -10.0952 & 2.0118 \\
\hline & Cntrol & $-7.0000^{\star}$ & 2.00000 & .013 & -13.0000 & -1.0000 \\
\hline \multirow{3}{*}{$\begin{array}{l}\text { Humanistic- } \\
\text { existential }\end{array}$} & Existential & -2.0833 & 2.00000 & 1.000 & -8.0000 & 3.0000 \\
\hline & Cognitive-existential & 4.0417 & 2.00000 & .000 & -2.0118 & 10.0952 \\
\hline & Cntrol & -3.0000 & 2.00000 & .000 & -9.0000 & 2.0000 \\
\hline \multirow[t]{3}{*}{ Cntrol } & Existential & 1.0833 & 2.00000 & 1.000 & -4.0000 & 7.0000 \\
\hline & Cognitiveexistential & $7.0000^{*}$ & 2.00000 & .013 & 1.0000 & 13.0000 \\
\hline & $\begin{array}{l}\text { Humanistic- } \\
\text { existential }\end{array}$ & 3.0000 & 2.00000 & .000 & -2.0000 & 9.0000 \\
\hline \multicolumn{7}{|c|}{ The error term is Mean Square (Error) $=18.187$. } \\
\hline
\end{tabular}

\section{Discussion}

The purpose of this research is to study the comparison of the effectiveness of existential, cognitive-existential, and humanistic-existential group psychotherapy on psychosomatic complaints among women with type 2 diabetes mellitus. 
A part of the results showed that the effect of the interventions in experimental groups of psychosomatic complaints was significant and stable compared to the control group. Findings of this research with research findings by Vos, Craig and Cooper (24) Tattersall, McCulloch and, Aveline (25) Nazari, Yarahmadi, and Zahrakar (26) Parizadeh, Hasan Abadi, Mashhadi, Taghizadeh Kermani (27) Bahmani B, Najjar MM, Sayyah M, Shafi-Abadi, Kashani (15), Kissane, et al. (28) and ghanbari givi and goli garmianaki (29) is aligned.

Other parts of results showed that the effect of the group humanistic-existential psychotherapy on reducing psychosomatic complaints about women with type 2 diabetes mellitus is stable and significant compared to existential and cognitiveexistential psychotherapy. Despite more or less aligned with reports by Ghanbari givi \& goli garmianaki (29), Suri (32), Derobertis (33), Krug, Granger, Yalom \& Schneider (34) and Guigno, Miranda, \& Hallmark (35) with this finding, These study does not compare the interventions and differ from the dependent variable and demographic characteristics of the subjects with the present study. Therefore, it can say that the findings of the present study seem innovative, and their confirmation requires further research.

Findings listed in Table 10, show cognitive-existential and humanistic-existential group psychotherapy methods compared to the simple existential method is effective. Also, show existential-humanistic group therapy, compared to existential and cognitive-existential interventions is more effective. This finding can be explained.

First, integrated cognitive-existential and humanistic-existential group psychotherapy methods are effective because they contain more than just the existential group psychotherapy method; in addition to dealing with existential themes, the cognitive-existential method also used the psycho-educational strategy to increase awareness about the body, the relationship between body and mind, and the mechanism of interaction between body and mind. Because of a part of the cognitive strategy devoted to informing the patients of the nature of the problem or disorder. These psycho-educational methods when integrated with existential strategy and cognitive methods of modification of cognitive distortions, play an important role in increasing the management of somatic changes due to psychological dynamics, so it can effective in reducing the psychosomatic complaints among women with type 2 diabetes mellitus. Second, the humanistic-existential method, in addition to the addressing existential issues facilitates the awareness of self-abilities in here and now and promotes unconditional acceptance of self enables clients to meet to increase somatic health. The humanistic-existential method focuses on finding the meaning of perfection and human experience to reach to increase health, vitality, and happiness. Because based on this method, an effective connection with nature and body is key to enhancement of health.

According to the addressing of the existential method to the relation between his or her psyche and body as the basic dimensions of human beings, and according to the increase of self-acceptance and self-confidence resulting from a humanistic-existential intervention, which is effective in increasing the self-care capacity of diabetic patients. Humanisticexistential group psychotherapy compared to existential and cognitive-existential psychotherapy is more effective in reducing psychosomatic complaints about women with type 2 diabetes mellitus.

\section{Strengths and limitations}

Limitations of this study were the lack of presence of both genders in experimental groups, and the society limited to women with type 2 diabetes mellitus refers to the Specialist Diabetes Clinic of Tohid Hospital in Sanandaj, which more limits generalization of this experimental research result. But, repetition of the present study, at other times and places, can be effective for enriching the health services available to women with type 2 diabetes mellitus; The use of group interventions that show have guaranteed effectiveness can reducing treatment costs of reducing the psychosomatic problems of women with type 2 diabetes. However, it can say that the findings of the present study seem innovative.

\section{Conclusion}


According to the findings of this study and according to this fact that diabetes has many negative effects on the biological, psychological, family, and social life of patients, repetition of the present study can enrich the health services available to women with type 2 diabetes mellitus. Efforts to the reduction of psychosomatic problems for women with type 2 diabetes seem essential; researches show type 2 diabetes has many negative effects on every dimension of patients' life and significant economic costs spent on their health care (36). Humanistic-existential group psychotherapy can used to cut psychosomatic problems by health centers and psycho-educational and medical centers, as well as centers of counseling and psychological services. However, to be a comparison of this study suggests that worthy's psychological intervention, namely existential-humanitarian intervention, offers better psychological services to these patients.

\section{Abbreviations}

No

\section{Declarations}

\section{Acknowledgements}

The support of the Deputy Research staff of the Faculty of Medical Sciences at the Kurdistan University of Medical Sciences , the compassionate staff at the Diabetes Clinic of Tohid Hospital in Sanandaj, are been appreciated. Also, the professional services and support of dear friends, Dr. Naser Yousefi and Dr. Arman Azizi are appreciated. The National Elite Foundation of Lorestan Province also supported the first author in providing this research by their facilities. Finally, sincerest thanks to the research subjects are expressed.

\section{Authors' contributions}

Gh NH contributed to the data collection, analysis, intervention and interpretation. M S and S Gh contributed to study conceptions and design, analysis, intervention and interpretation. All authors read and approved the final version of the manuscript.

\section{Funding}

No

\section{Availability of data and materials}

No

\section{Ethics approved and consent to participate}

The proposal of this research was examined in the meeting of the Regional Research Ethics Committee of Lorestan University of Medical Sciences and the ethics code of IR.LUMS.REC.1397.179 was obtained from the Iran National Committee for Ethics in Biomedical Research. During the research, all subjects were informed that their information was collected for research purposes and that the identities of the respondents were kept confidential. All participants signed written consent. It was also stated that those interested can be informed of the research results by e-mail.

\section{Consent for publication}

All the participants gave consent for result report from their participation in therapeutic sessions to be used in this manuscript. Also, all participants signed a written consent.

\section{Competing interests}

Page 16/18 
This article derived from the doctoral dissertation of the first author. The authors declare that they have no competing interests.

\section{Author details}

1. Ph.D. Student Psychology of Department of Psychology, Faculty of Literature and Humanities, Lorestan University, Khorramabad, Iran.

2. Department of Psychology, Faculty of Literature and Humanities, Lorestan University, Khorramabad, 5th Kilometer of Khorramabad-Boroujerd Highway, Khorramabad, Lorestan, Iran.

3. Department of Psychology, Faculty of Literature and Humanities, Lorestan University, Khorramabad, 5th Kilometer of Khorramabad-Boroujerd Highway, Khorramabad, Lorestan, Iran.

\section{References}

1. Golparvar M, Khatonabadi G. Structural Model of the Relationship between Bullying in Hospital Environments and Negative effect and Psychosomatic Complaints among female Nurses. Journal of Nursing Education. 2017;4(5):52-9.

2. Ostadzadeh A, Ebrahimi A, Mozaffari M. Investigating the relationship between quality of life with adherence and history of treatment (drug therapy) without psychotherapy and demographic characteristics in patients with type 2 diabetes. Journal of Fundamentals of Mental Health. 2017;19(special issue):167-73.

3. Heidari A, Aghaei A, Afshar H. Comparing Problem-Solving Skills and Cognitive Emotion Regulation in Patients with Psychosomatic Symptoms and Control Population in Isfahan City, Iran. Journal of Isfahan Medical School. 2018;35:1660-7.

4. Sridhar G. Psychiatric co-morbidity \& diabetes. Indian Journal of Medical Research. 2007;125(3):311.

5. Trief PM, Ouimette P, Wade M, Shanahan P, Weinstock RS. Post-traumatic stress disorder and diabetes: co-morbidity and outcomes in a male veterans sample. Journal of behavioral medicine. 2006;29(5):411-8.

6. Gregg EW, Gu Q, Cheng YJ, Narayan KV, Cowie CC. Mortality trends in men and women with diabetes, 1971 to 2000. Annals of internal medicine. 2007;147(3):149-55.

7. Steed L, Cooke D, Newman S. A systematic review of psychosocial outcomes following education, self-management and psychological interventions in diabetes mellitus. Patient education and counseling. 2003;51(1):5-15.

8. Rashid Chandio T, Fatima S. Siren Kierkegaard and jean-Paul Sartre's existentialist approach: A comparative, textual analysis.

9. Sharf RS. Theories of psychotherapy \& counseling: Concepts and cases: Cengage Learning; 2015.

10. Frankel B. Existential Issues in Group Psychotherapy. International Journal of Group Psychotherapy. 2002;52(2):215-31.

11. Schulenberg SE. Clarifying and Furthering Existential Psychotherapy: Springer; 2016.

12. Van Deurzen E, Adams M. Skills in existential counselling \& psychotherapy: Sage; 2016.

13. Corey G, Corey MS. Group psychotherapy. 2016.

14. Askari sd, Nasiri Hanis g, Panaghi L. Effectiveness of participation in group existential analysis sessions on worry. The Journal Of Psychological Science. 2015;14(54):226-40.

15. Bahmani B, Najjar MM, Sayyah M, Shafi-Abadi A, Kashani HH. The effectiveness of cognitive-existential group therapy on increasing hope and decreasing depression in women-treated with haemodialysis. Global journal of health science. 2016;8(6):219.

16. Bahmani B, Etemadi A, Shafiabadi A, Delavar A, Ghanbari Motlagh A. Cognitive-existential group therapy and cognitive therapy-oriented training in breast cancer patients. J Dev Psychol. 2008;6(23):201-14. 
17. Corrie S, Milton M. The relationship between existential-phenomenological and cognitive-behaviour therapies. European Journal of Psychotherapy \& Counselling. 2000;3(1):7-24.

18. Watson JC, Schneider K. Humanistic-existential theories. 2016.

19. Schneider KJ, Krug OT. Existential-humanistic therapy: American Psychological Association Washington, DC; 2010.

20. Karvasarsky B. Encyclopedia of psychotherapy. St Petersburg, Ed Piter. 2002.

21. Shabbeh Z, Feizi A, Afshar H, Hassanzade Kashtali A, Adibi P. Identifying the profiles of psychosomatic disorders in an iranian adult population and their relation to psychological problems. Journal of Mazandaran University of Medical Sciences. 2016;26(137):82-94.

22. Hajloo N. Psychometric properties of Takata and Sakata's psychosomatic complaints scale among Iranian university students. Journal of Research in Behavioural Sciences. 2013;10(3):204-.

23. Manavipour D, Miri LS. Early Maladaptive Schemas in Patients with Psychosomatic Disorder and Multiple Sclerosis. The Neuroscience Journal of Shefaye Khatam. 2017;5(1):40-7.

24. Vos J, Craig M, Cooper M. Existential therapies: A meta-analysis of their effects on psychological outcomes. Journal of consulting and clinical psychology. 2015;83(1):115.

25. Tattersall RB, McCulloch DK, Aveline M. Group therapy in the treatment of diabetes. Diabetes Care. 1985;8(2):180-8.

26. NAZARI AM, YARAHMADI H, ZAHRAKAR K. The effectiveness of existential group psychotherapy on marital satisfaction in women with type 2 diabetes. 2014.

27. Parizadeh H, Hasan Abadi H, Mashhadi A, Taghizadeh Kermani A. Investigating Effectiveness of Existential and Reality Group-Therapy in Treatment of Body-Image Problem in Women Who Undergo Mastectomy. The Iranian Journal of Obstetrics, Gynecology and Infertility. 2012;15(22):27-35.

28. Kissane DW, Bloch S, Smith GC, Miach P, Clarke DM, Ikin J, et al. Cognitive-existential group psychotherapy for women with primary breast cancer: a randomised controlled trial. Psycho-Oncology: Journal of the Psychological, Social and Behavioral Dimensions of Cancer. 2003;12(6):532-46.

29. ghanbari givi h, goli garmianaki e. Efficacy of humanistic existential group therapy in reducing hopelessness impulsivity and stress related dissociative and paranoid symptoms in borderline personality disorder. Clinical Psychology Studies. 2011;1(2):120-35.

30. Takata Y, Sakata Y. Development of a psychosomatic complaints scale for adolescents. Psychiatry and clinical neurosciences. 2004;58(1):3-7.

31. Ottens AJ, Hanna FJ. Cognitive and existential therapies: Toward an integration. Psychotherapy: Theory, Research, Practice, Training. 1998;35(3):312.

32. Suri R. Working With the Elderly: An Existential-Humanistic Approach. Journal of Humanistic Psychology. 2010;50(2):175-86.

33. Derobertis EM. Charlotte Bühler's existential-humanistic contributions to child and adolescent psychology. Journal of Humanistic Psychology. 2006;46(1):48-76.

34. Krug OT, Granger N, Yalom I, Schneider KJ. Case Illustrations of Existential-Humanistic and Existential-Integrative Therapy. The Wiley World Handbook of Existential Therapy. 2019:267-81.

35. Guigno C, Miranda W, Hallmark C. Existential/Humanistic Treatment Modalities for Counseling Returning Combat Veterans. J Ment Disord Treat. 2017;3(139):2.

36. Parnan A, Tafazolim M, Azmoude E. Comparison of the Sexual Function among Women with and without Diabetes. Journal of Midwifery and Reproductive Health. 2017;5(4):1090-7.

37. Mullan H. "Existential” Therapists and Their Group Therapy Practices. International Journal of Group Psychotherapy. 1992;42(4):453-68.

38. Craig M, Vos J, Cooper M, Correia EA. Existential psychotherapies. 2016.

Page $18 / 18$ 